\title{
Menakar Peran Pemerintah Dan Akademisi Terhadap Pengembangan UMKM
}

\author{
Maya Yusnita dan Dian Prihardini Wibawa \\ Universitas Bangka Belitung \\ Email: mayayusnitaubb@gmail.com dan dianpw.mustafa@gmail.com \\ Diterima: November 2019; Dipublikasikan Januari 2020
}

\begin{abstract}
ABSTRAK
Penelitian ini bertujuan untuk mengukur sejauh mana peran pemerintah dan akademisi dalam mengembangkan Usaha Mikro Kecil dan Menengah (UMKM) sebagai pemberdaya ekonomi rakyat. Responden dalam penelitian ini berjumlah 51 orang yang merupakan pelaku UMKM di Pangkalpinang. Metode penelitian menggunakan wawancara dan kuesioner. Teknik analisis data yang digunakan yaitu analisis deskriptif kuantitatif. Hasil penelitian menunjukkan: (a) Peran pemerintah terhadap pengembangan UMKM termasuk dalam kategori sangat tinggi. Hal ini berarti pemerintah kota Pangkalpinang sudah sangat baik dalam mendukung pengembangan UMKM. Peran pemerintah yang paling dirasakan yaitu dalam bentuk pembinaan serta koordinasi dengan para pelaku UMKM. (b) Peran akademisi terhadap pengembangan UMKM termasuk dalam kategori tinggi. Para akademisi khususnya di Pangkalpinang sudah dirasa baik dalam melakukan sinergi dengan pemerintah maupun pelaku UMKM sendiri baik dalam bidang penelitian, maupun pengabdian kepada masyarakat yang berkaitan dengan UMKM.
\end{abstract}

Kata Kunci: pemerintah; akademisi; UMKM.

\begin{abstract}
This study aims to measure the extent of the role of government and academics in developing Micro, Small and Medium Enterprises (MSMEs) as empowering the people's economy. Respondents in this study were 51 people who were MSMEs in Pangkalpinang. The research method used are interviews and questionnaires. The data analysis technique used is quantitative descriptive analysis. The results showed: (a) The role of the government towards the development of MSMEs in the very high category. This means that the Pangkalpinang city government has been very good in supporting the development of MSMEs. The role of government is most felt in the form of coaching and coordination with MSMEs. (b) The role of academics in the development of MSMEs in the high category. Academics, especially in Pangkalpinang, have been considered good in synergizing with the government and the MSME actors themselves both in the field of research, as well as community service related to MSMEs.
\end{abstract}

Keywords: government; academics; MSMEs. 


\section{PENDAHULUAN}

Pada tahun 2009 Indonesia pernah dilanda krisis global, namun tidak separah krisis moneter yang terjadi pada tahun 1997-1998. Salah satu yang diutarakan dalam kebijakan pemerintah dalam mendukung perekonomian bangsa adalah dengan kewirausahaan yang dinamis serta mampu mendukung program dari pengusaha Indonesia sebagai salah satu mitra dalam peningkatan perekonomian secara umum (Sulastri, 2015). Usaha Kecil Menengah (UKM) mempunyai peran strategis dalam pembangunan ekonomi nasional. Selain berperan dalam pertumbuhan ekonomi dan penyerapan tenaga kerja, UKM juga berperan dalam pendistribusian hasil-hasil pembangunan. Mengingat pengalaman yang telah dihadapi oleh Indonesia selama krisis tersebut, kiranya tidak berlebihan apabila pengembangan sektor swasta difokuskan pada UKM, terlebih lagi unit usaha ini seringkali terabaikan dikarenakan hasil produksi yang masih dalam skala kecil serta belum mampu bersaing dengan unit usaha lainnya (Kristiyanti, 2012).

Pengembangan UMKM perlu mendapat perhatian yang besar baik dari pemerintah maupun masyarakat agar dapat berkembang secara lebih kompetitif. Kebijakan pemerintah perlu diupayakan agar lebih kondusif bagi tumbuh dan berkembangnya UMKM. Pemerintah perlu meningkatkan perannya dalam memberdayakan UMKM di samping mengembangkan kemitraan usaha yang saling menguntungkan antara pengusaha besar dengan pengusaha kecil, dan meningkatkan kualitas Sumber Daya Manusianya (Wuryandai, 2013). Pentingnya peran perguruan tinggi dalam mencetak sumber daya manusia yang berjiwa inovator dan technopreneur harus didukung oleh kebijakan pemerintah Indonesia agar bisa memberikan iklim yang kondusif (Marlinah, 2019). Penelitian yang dilakukan oleh Taranggana Gani Putra (2015) menghasilkan bahwa terdapat beberapa peran pemerintah yaitu sebagai fasilitator dan katalisator. Pemerintah Kabupaten Jombang sebagai fasilitator melalui berbagai kegiatan fasilitasi yang meliputi pelatihan manajamen usaha dan proses produksi, bantuan sarana dan prasarana berupa pemberian alat penumbuk kaca dan tungku pembakaran. Pemerintah Kabupaten Jombang sebagai katalisator melalui berbagai kegiatan yang meliputi penetapan manic-manik kaca sebagai produk unggulan kabupaten Jombang, promosi produk dengan mengikuti pameran skala nasional dan internasional, bantuan pengurusan HAKI serta penyediaan modal bergulir dengan bunga rendah.

Penelitian oleh Reni Endang Sulastri dkk (2015) mengenai peran pemerintah dan akademisi dalam memajukan Industri Kreatif (Kasus pada UMKM Kerajinan Sulaman di Kota Pariaman) menemukan bahwa peran pemerintah selama ini banyak dilakukan untuk pengrajin dan pengusaha, tetapi keinginan dari pengrajin dan pengusaha yang sangat sulit mengubah diri mereka sendiri menjadi kendala pemerintah dalam meningkatkan kualitas usaha. Sedangkan, akademisi berperan dalam berbagai kegiatan, seperti melakukan pembinaan administrasi dan keuangan usaha, mentransfer Teknologi Tepat Guna (TTG) pada UKM, serta memberikan motivasi dan semangat kepada para wirausahawan agar mampu mengembangkan usaha yang dimiliki.

Selanjutnya, penelitian yang dilakukan oleh Zul Asfi Arroyhan Daulay pada Tahun 2018, menghasilkan temuan bahwa pola interaksi antara ketiga aktor yaitu pelaku bisnis, pemerintah dan akademisi, harus berkolaborasi secara simbiosis mutualisme dalam merancang dan mengembangkan ekonomi kreatif. Strategi yang digunakan untuk mengembangkan ekonomi kreatif tersebut melalui strategi agresif atau strategi S-0 yaitu menggunakan kekuatan untuk memanfaatkan peluang. 
Penelitian oleh Prayitno dkk (2019) menghasilkan bahwa Politeknik adalah perguruan tinggi vokasi yang keilmuanya aplikatif menjadi harapan baru bagi para pelaku UMKM untuk bisa membantu permasalahan yang dialami dalam menghadapi persaingan dan perkembangan usaha ditengah ketidakpastian. Peran Politeknik membantu dari sisi manajemen, akuntasi, hubungan dengan perbankan, marketing, jaringan dan solusi praktis maka dampaknya para pelaku UMKM mampu mengikuti perkembangan globalisasi dan bersaing dengan perusahaan Global.

Penelitian oleh Wahyudiono (2018) menyimpulkan bahwa peran perguruan tinggi dalam memperkuat daya saing UMKM kawasan wisata religi masih belum berjalan optimal, khususnya penerapan program klinik, program pelatihan, program pendampingan dan bina mitra UMKM, sehingga memberi efek yang kurang baik bagi perkembangan dan keberlanjutan praktek manajemen UMKM dan keberhasilan usaha dimasa mendatang. Dewi Kurniawati (2015) menghasilkan temuan bahwa faktor-faktor yang penting dalam pengembangan UMKM di Pusat Kuliner Belut adalah varian produk olahan belut; persaingan dengan berbagai produk oleh-oleh khas kota Yogyakarta; program pelatihan dari Dinas Perikanan Sleman; motivasi untuk mengembangkan usaha; keahlian dan keterampilan, kreatif dan inovatif, promosi, dan informasi pasar. Faktorfaktor yang telah terindentifikasi tersebut dapat digunakan sebagai acuan bagi Pemerintah Daerah untuk menyusun keputusan strategis dalam rangka meningkatkan eksistensi UMKM di Pusat Kuliner Belut.

\section{TINJAUAN PUSTAKA}

\section{Definisi dan Karakteristik UMKM}

Usaha Mikro, Kecil, dan Menengah (UMKM) memiliki definisi yang berbeda pada setiap literatur baik menurut beberapa instansi, lembaga maupun undang-undang. Undang-Undang Nomor 20 Tahun 2008 pasal 6 membagi kriteria UMKM berdasarkan jumlah kekayaan bersih dan hasil penjualan tahunan. Sedangkan Badan Pusat Statistik (BPS) membagi kriteria UMKM berdasarkan jumlah tenaga kerja mereka (Darwanto, 2013).

Menurut Undang-Undang Republik Indonesia Nomor 20 Tahun 2008 tentang Usaha Mikro, Kecil dan Menengah (UMKM):

a. Usaha Mikro, yaitu usaha produktif milik orang perorangan atau badan usaha milik perorangan yang memenuhi kriteria yakni memiliki kekayaan bersih paling banyak Rp50.000.000 (lima puluh juta rupiah) tidak termasuk tanah dan bangunan tempat usaha serta memiliki hasil penjualan tahunan paling banyak Rp300.000.000 (tiga ratus juta rupiah)

b. Usaha Kecil, yaitu usaha ekonomi produktif yang berdiri sendiri yang dilakukan oleh orang perorangan atau badan usaha yang bukan merupakan anak perusahaan atau bukan cabang perusahaan yang dimiliki, dikuasai atau menjadi bagian baik langsung maupun tidak langsung dari usaha menengah atau usaha besar. Memenuhi kriteria yakni memiliki kekayaan bersih lebih dari Rp50.000.000 (lima puluh juta rupiah) sampai dengan paling banyak Rp500.000.000 (lima ratus juta rupiah) tidak termasuk tanah dan bangunan tempat usaha; atau Memiliki hasil penjualan tahunan lebih dari Rp300.000.000 (tiga ratus juta rupiah) sampai dengan paling banyak Rp2.500.000.000 (dua milyar lima ratus juta rupiah)

c. Usaha Menengah, yaitu usaha ekonomi produktif yang berdiri sendiri, yang dilakukan oleh orang perorangan atau badan usaha yang bukan merupakan anak perusahaan atau cabang perusahaan yang dimiliki, dikuasai, atau menjadi bagian baik langsung 
maupun tidak langsung dengan usaha kecil atau usaha besar. Memenuhi kriteria memiliki hasil kekayaan bersih lebih dari Rp500.000.000 (lima ratus juta rupiah) sampai dengan paling banyak Rp10.000.000.000 (sepuluh milyar rupiah) tidak termasuk tanah dan bangunan tempat usaha; atau memiliki hasil penjualan tahunan lebih dari Rp2.500.000.000 (dua milyar lima ratus juta rupiah) sampai dengan paling banyak Rp50.000.000.000 (lima puluh milyar rupiah).

Menurut Tambunan (2002), karakteristik UKM yang memiliki keunggulan kompetitif sebagai berikut : (a) Memiliki kualitas SDM yang baik; (b) Pemanfaatan teknologi yang optimal; (c) Mampu melakukan efisiensi dan meningkatkan produktivitas; (d) Mampu meningkatkan kualitas produk; (e) Memiliki akses promosi yang luas; (f) Memiliki sistem manajemen kualitas yang terstruktur; (g) Sumber daya modal yang memadai; (h) Memiliki jaringan bisnis yang luas; serta (i) Memiliki jiwa kewirausahaan (Ramadini, 2016). Badan Pusat Statistik (BPS) mendefinisikan UMKM berdasarkan kuantitas tenaga kerja. Usaha kecil merupakan usaha yang memiliki jumlah tenaga kerja 5-19 orang, sedangkan usaha menengah merupakan usaha yang memiliki jumlah tenaga kerja 20-99 orang. Definisi lain dari Usaha Kecil berdasarkan Keputusan Menteri Keuangan No. 316/KMK 016/1994 adalah bentuk perorangan atau badan usaha yang telah melakukan kegiatan/usaha dengan penjualan/omset per tahun setinggitingginya Rp 600.000.000 atau aset setinggi-tingginya Rp 600.000.000 (di luar tanah dan bangunan yang ditempati) (Sulastri, 2014).

\section{Hambatan Pengembangan UMKM}

Beberapa permasalahan dan hambatan yang ditemui baik dalam hal manajemen secara internal dan eksternal maupun dalam pelaksanaan kegiatan usaha yang antara lain sebagai berikut:

a. Terbatasnya modal yang dimiliki oleh pelaku UMKM

b. Masih rendahnya pengetahuan dan pemahaman pelaku UMKM dalam mengembangkan dan mempertahankan usaha

c. Kurangnya ketersedian sarana dan prasarana yang dibutuhkan oleh pelaku UMKM dalam membantu pengembangan dan peningkatan usahanya.

d. Adanya hambatan secara eksternal seperti kesediaan tenaga listrik yang dianggap mengganggu kegiatan operasional dari UMKM

e. Kurangnya pemahaman dari pelaku UMKM tentang strategi, sistem dan prosespemasaran bagi hasil produksinya

f. Kurang pahamnya mengenai birokrasi dalam dunia usaha untuk dapat menembus pasar yang lebih luas dari pasar lokal yang telah mereka lakukan dan minimnya atau sedikitnya informasi mengenai pengembanganusaha bagi UMKM

g. Kemampuan penggunaan atau penerapan teknologi dalam menunjang peningkatan usaha serta kemampuan penerapan standar produk UMKMyang masih terbatas

h. Akses sarana informasi yang dapat diakses oleh masyarakat masih terbatas dan kebijakan yang masih terlihat bias bagi pelaku UMKM, sehingga mengurangi ruang gerak bagi pelaku UMKM (Ariani \& Utomo, 2017) dalam (Hendrawan, 2019).

Sesuai dengan cirinya, UKM sangat rentan dengan berbagai keterbatasan dan permasalahan, beberapa diantaranya: (Yurilsya, 2012).

a. Biasanya berbentuk usaha perorangan dan belum berbadan hukum perusahaan

b. Aspek legalitas usaha lemah

c. Struktur organisasi bersifat sederhana dengan pembagian kerja yang tidak baku 
d. Kebanyakan tidak mempunyai laporan keuangan dan tidak melakukan pemisahan antara kekayaan pribadi dengan kekayaan perusahaan

e. Kualitas manajemen rendah dan jarang yang memiliki rencana usaha

f. Sumber utama modal usaha adalah modal pribadi

g. Sumber Daya Manusia (SDM) terbatas

h. Pemilik memiliki ikatan batin yang kuat dengan perusahaan, sehingga seluruh kewajiban perusahaan juga menjadi kewajiban pemilik.

Kendala lain yang dihadapi UMKM adalah keterkaitan dengan prospek usaha yang kurang jelas serta perencanaan, visi dan misi yang belum mantap. Hal ini terjadi karena umumnya UMKM bersifat income gathering yaitu menaikkan pendapatan, dengan ciri-ciri: (1) Merupakan usaha milik keluarga; (2) Menggunakan teknologi yang masih relatif sederhana; (3) Kurang memiliki akses permodalan (bankable); serta (4) Tidak ada pemisahan modal usaha dengan kebutuhan pribadi. Masalah lain yang dihadapi dan sekaligus menjadi kelemahan UMKM adalah kurangnya akses informasi, khususnya informasi pasar. Hal tersebut menjadi kendala dalam hal memasarkan produkproduknya, karena dengan terbatasnya akses informasi pasar, mengakibatkan rendahnya orientasi pasar serta lemahnya daya saing global. Miskinnya informasi mengenai pasar tersebut, menjadikan UMKM tidak dapat mengarahkan pengembangan usahanya secara jelas dan fokus, sehingga perkembangannya mengalami stagnasi (Sobana, 2018).

\section{METODE PENELITIAN}

Teknik pengumpulan data menggunakan metode wawancara dan kuesioner. Penelitian ini menggunakan metode probability sampling (simple random sampling) dengan memilih secara acak (tidak memperhatikan strata dalam populasi penelitian) sebanyak 51 pelaku UMKM di Pangkalpinang yang terbagi atas komoditi pangan, sandang serta kerajinan. Teknik analisis data menggunakan analisis deskriptif kuantitatif.

Teknik analisis data yang digunakan dalam penelitian ini adalah teknik analisis kuantitaif dengan statistik deskriptif. Statistik deskiptif adalah mendeskripsikan atau menggambarkan data statistik yang telah terkumpul, kemudian digunkan untuk menganalisis data sebagaimana adanya tanpa bermaksud membuat kesimpulan yang berlaku untuk umum atau generalisasi (Sugiyono, 2014).

Tabel 1: Skala Interval

\begin{tabular}{|c|l|l|}
\hline No. & \multicolumn{1}{|c|}{ Skala } & \multicolumn{1}{c|}{ Keterangan } \\
\hline 1 & $1.00-1.80$ & Sangat Rendah \\
\hline 2 & $1.81-2.60$ & Rendah \\
\hline 3 & $2.61-3.40$ & Sedang \\
\hline 4 & $3.41-4.20$ & Tinggi \\
\hline 5 & $4.21-5.00$ & Sangat Tinggi \\
\hline
\end{tabular}

Sumber: Sugiyono, 2014

Pada analisis deskriptif, peneliti memberikan skor setiap hasil jawaban responden. Item Sangat Setuju (Skor 5), Setuju (Skor 4), Ragu-ragu (Skor 3), Tidak Setuju (Skor 2) dan Sangat Tidak Setuju (Skor 1). Terdapat 8 pernyataan yang terbagi menjadi peran pemerintah dan perguruan tinggi dalam pengembangan UMKM di Pangkalpinang. Berikut merupakan hasil jawaban dari responden. 


\section{Deskripsi Responden Berdasarkan Usia}

\section{HASIL DAN PEMBAHASAN}

Tabel 2: Identitas Responden berdasarkan Usia

\begin{tabular}{|c|c|r|}
\hline Usia (Tahun) & Jumlah (Orang) & \multicolumn{1}{|c|}{ Persentase (\%) } \\
\hline $25-30$ & 6 & 11,8 \\
\hline $30-35$ & 15 & 41,2 \\
\hline $35-40$ & 7 & 54,9 \\
\hline$>40$ & 23 & 100,0 \\
\hline Total & $\mathbf{5 1}$ & $\mathbf{1 0 0}$ \\
\hline
\end{tabular}

Sumber: Data Diolah, 2019.

Tabel 2 menunjukkan bahwa usia para pelaku UMKM di Pangkalpinang didominasi pada rentang 35-40 Tahun (54,9\%) dan 30-35 Tahun (41,2\%).

Deskripsi Responden Berdasarkan Jenis Kelamin

Tabel 3: Identitas Responden berdasarkan Jenis Kelamin

\begin{tabular}{|c|c|r|}
\hline Jenis Kelamin & Jumlah (Orang) & \multicolumn{1}{|c|}{ Persentase (\%) } \\
\hline Laki-laki & 4 & 7,8 \\
\hline Perempuan & 47 & 92,2 \\
\hline Total & $\mathbf{5 1}$ & $\mathbf{1 0 0}$ \\
\hline
\end{tabular}

Sumber: Data primer diolah, 2019

Berdasarkan tabel 3 tersebut terlihat bahwa sebagian besar para pelaku UMKM di Pangkalpinang berjenis kelamin perempuan yaitu sebanyak 47 orang $(92,2 \%)$.

\section{Deskripsi Responden Berdasarkan Lama Usaha}

Tabel 4: Identitas Responden berdasarkan Lama Usaha

\begin{tabular}{|c|c|r|}
\hline $\begin{array}{c}\text { Lama Usaha } \\
\text { (Tahun) }\end{array}$ & Jumlah (Orang) & Persentase (\%) \\
\hline$<5$ & 31 & 60,8 \\
\hline $5-10$ & 13 & 25,5 \\
\hline $10-15$ & 5 & 9,8 \\
\hline$>15$ & 2 & $\mathbf{1 0 0}$ \\
\hline Total & $\mathbf{5 1}$ & 3,9 \\
\hline
\end{tabular}

Sumber: Data primer diolah, 2019

Berdasarkan tabel 4 tersebut terlihat bahwa dari 51 responden, sebagian besar para pelaku UMKM di Pangkalpinang baru menjalankan usahanya $<5$ tahun $(60,8 \%)$.

\section{Peran Pemerintah Terhadap Pengembangan UMKM}

Tabel 5:Pemerintah Selalu Melakukan Pembinaan Terhadap Inkubasi Bisnis

\begin{tabular}{|c|l|c|r|}
\hline No & Kategori & Frekuensi & Persentase (\%) \\
\hline 1 & Ragu-ragu & 3 & 5,9 \\
\hline 2 & Setuju & 22 & 43,1 \\
\hline 3 & Sangat Setuju & 26 & 51 \\
\hline & Total & $\mathbf{5 1}$ & $\mathbf{1 0 0}$ \\
\hline
\end{tabular}

Sumber: Data primer diolah, 2019 
Berdasarkan Tabel 5 diatas, dapat diketahui bahwa sebagian besar pelaku UMKM berpendapat bahwa Pemerintah selalu melakukan pembinaan terhadap inkubasi bisnis $(51 \%)$.

Tabel 6: Pemerintah Selalu Melakukan Koordinasi Dengan UMKM

\begin{tabular}{|c|l|c|r|}
\hline No & Kategori & Frekuensi & Persentase (\%) \\
\hline 1 & Ragu-ragu & 2 & 3,9 \\
\hline 2 & Setuju & 24 & 47,1 \\
\hline 3 & Sangat Setuju & 25 & 49,0 \\
\hline & Total & $\mathbf{5 1}$ & $\mathbf{1 0 0}$ \\
\hline
\end{tabular}

Sumber: Data primer diolah, 2019

Berdasarkan Tabel 6 diatas, dapat diketahui bahwa sebagian besar pelaku UMKM berpendapat bahwa Pemerintah selalu melakukan koordinasi dengan UMKM $(51 \%)$.

Tabel 7: Pemerintah selalu memberikan Bantuan Alat dan Bahan Produksi Usaha

\begin{tabular}{|c|l|r|r|}
\hline No & \multicolumn{1}{|c|}{ Kategori } & \multicolumn{1}{|c|}{ Frekuensi } & Persentase (\%) \\
\hline 1 & Sangat Tidak Setuju & 2 & 3,9 \\
\hline 2 & Tidak Setuju & 1 & 2,0 \\
\hline 3 & Ragu-ragu & 10 & 19,6 \\
\hline 4 & Setuju & 20 & 39,2 \\
\hline 5 & Sangat Setuju & 18 & 35,3 \\
\hline & Total & $\mathbf{5 1}$ & $\mathbf{1 0 0}$ \\
\hline
\end{tabular}

Sumber: Data primer diolah, 2019

Berdasarkan Tabel 7 diatas, dapat diketahui bahwa sebagian besar pelaku UMKM setuju bahwa pemerintah selalu memberikan bantuan alat dan bahan produksi usaha. Akan tetapi, terdapat 3,9\% dari pelaku UMKM yang berpendapat bahwa Pemerintah tidak konsisten dalam memberikan bantuan baik berupa alat maupun bahan produksi usaha.

Tabel 8:

Pemerintah Selalu Melakukan Monitoring (Pengawasan)

Dalam Pelaksanaan Kegiatan"

\begin{tabular}{|c|l|r|r|}
\hline No & \multicolumn{1}{|c|}{ Kategori } & \multicolumn{1}{|c|}{ Frekuensi } & \multicolumn{1}{c|}{ Persentase (\%) } \\
\hline 1 & Ragu-ragu & 6 & 11,8 \\
\hline 2 & Setuju & 29 & 56,9 \\
\hline 3 & Sangat Setuju & 16 & 31,4 \\
\hline & Total & $\mathbf{5 1}$ & $\mathbf{1 0 0}$ \\
\hline
\end{tabular}

Sumber: Data primer diolah, 2019

Berdasarkan tabel 8, dapat diketahui bahwa sebagian besar pelaku UMKM berpendapat bahwa pemerintah selalu melakukan monitoring (pengawasan) dalam pelaksanaan kegiatan. 


\section{Peran Akademisi Terhadap Pengembangan UMKM}

Tabel 9.

Perguruan Tinggi selalu memiliki Perencanaan, Pelaksanaan dan Evaluasi terhadap Kegiatan Penelitian dan Pengabdian

kepada Masyarakat yang berkaitan dengan UMKM

\begin{tabular}{|c|l|r|r|}
\hline No & \multicolumn{1}{|c|}{ Kategori } & \multicolumn{1}{|c|}{ Frekuensi } & Persentase (\%) \\
\hline 1 & Ragu-ragu & 11 & 21,6 \\
\hline 2 & Setuju & 28 & 54,9 \\
\hline 3 & Sangat Setuju & 12 & 23,5 \\
\hline & Total & 51 & 100 \\
\hline
\end{tabular}

Sumber: Data primer diolah, 2019

Berdasarkan tabel 9 diatas, dapat diketahui bahwa sebagian besar pelaku UMKM sependapat bahwa Perguruan Tinggi di Bangka Belitung selalu memiliki perencanaan, pelaksanaan dan evaluasi terhadap kegiatan penelitian dan pengabdian kepada maasyarakat yang berkaitan dengan UMKM.

Tabel 10.

Perguruan Tinggi Aktif Dalam Menyelenggarakan

Kegiatan Inkubasi Bisnis

\begin{tabular}{|c|l|r|r|}
\hline No & \multicolumn{1}{|c|}{ Kategori } & \multicolumn{1}{|c|}{ Frekuensi } & Persentase (\%) \\
\hline 1 & Ragu-ragu & 13 & 25,5 \\
\hline 2 & Setuju & 30 & 58,8 \\
\hline 3 & Sangat Setuju & 8 & 15,7 \\
\hline & Total & 51 & 100 \\
\hline
\end{tabular}

Sumber: Data primer diolah, 2019

Berdasarkan Tabel 10, dapat diketahui bahwa sebagian besar pelaku UMKM sependapat bahwa Perguruan Tinggi aktif dalam menyelenggarakan kegiatan inkubasi bisnis dalam pengembangan UMKM di Pangkalpinang.

Tabel 11.

Perguruan Tinggi selalu membangun Sinergitas dengan Pemerintah dan Pelaku UMKM

\begin{tabular}{|c|l|r|r|}
\hline No & \multicolumn{1}{|c|}{ Kategori } & \multicolumn{1}{|c|}{ Frekuensi } & Persentase (\%) \\
\hline 1 & Tidak Setuju & 1 & 2,0 \\
\hline 2 & Ragu-ragu & 11 & 21,6 \\
\hline 3 & Setuju & 25 & 49,0 \\
\hline 4 & Sangat Setuju & 14 & 27,5 \\
\hline & Total & 51 & 100 \\
\hline
\end{tabular}

Sumber: Data primer diolah, 2019

Berdasarkan tabel 11, dapat diketahui bahwa sebagian besar pelaku UMKM sependapat bahwa Perguruan Tinggi selalu membangun sinergitas dengan pemerintah dan pelaku UMKM. Akan tetapi, sebanyak $2 \%$ dari pelaku UMKM yang berpendapat bahwa Perguruan Tinggi tidak selalu membangun sinergitas (kerjasama) dengan pemerintah dan pelaku UMKM. 
Tabel 12.

Perguruan Tinggi Aktif Melakukan Penelitian (Kajian) Mengenai UMKM Serta Mendiseminasikannya

\begin{tabular}{|c|l|r|r|}
\hline No & \multicolumn{1}{|c|}{ Kategori } & \multicolumn{1}{|c|}{ Frekuensi } & \multicolumn{1}{c|}{ Persentase (\%) } \\
\hline 1 & Ragu-ragu & 11 & 21,6 \\
\hline 2 & Setuju & 36 & 70,6 \\
\hline 3 & Sangat Setuju & 4 & 7,8 \\
\hline & Total & 51 & 100 \\
\hline
\end{tabular}

Sumber: Data primer diolah, 2019

Berdasarkan Tabel 12, dapat diketahui bahwa sebagian besar pelaku UMKM sependapat bahwa Perguruan Tinggi aktif dalam melakukan penelitian (kajian) mengenai UMKM serta mendiseminasikan hasil penelitian tersebut.

\section{Pembahasan}

Tabel 13.

Rata-rata Skor Peran Pemerintah terhadap Pengembangan UMKM

\begin{tabular}{|l|r|c|}
\hline \multicolumn{1}{|c|}{ Item } & Mean & Keterangan \\
\hline Pernyataan 1 & 4.45 & Sangat Tinggi \\
\hline Pernyataan 2 & 4.45 & Sangat Tinggi \\
\hline Pernyataan 3 & 4.00 & Tinggi \\
\hline Pernyataan 4 & 4.20 & Tinggi \\
\hline Rata-rata & 4.27 & Sangat Tinggi \\
\hline
\end{tabular}

Sumber: Data primer diolah, 2019

Tabel 13 diatas memperlihatkan bahwa peran pemerintah terhadap pengembangan UMKM memiliki nilai rata-rata sebesar 4.27 yang termasuk dalam kategori sangat tinggi.

Tabel 14.

Rata-rata Skor Peran Akademisi terhadap Pengembangan UMKM

\begin{tabular}{|l|r|c|}
\hline \multicolumn{1}{|c|}{ Item } & Mean & Keterangan \\
\hline Pernyataan 1 & 4.02 & Tinggi \\
\hline Pernyataan 2 & 3.90 & Tinggi \\
\hline Pernyataan 3 & 4.02 & Tinggi \\
\hline Pernyataan 4 & 3.86 & Tinggi \\
\hline Rata-rata & 3.95 & Tinggi \\
\hline
\end{tabular}

Sumber: Data primer diolah, 2019

Tabel 14 diatas memperlihatkan bahwa peran akademisi terhadap pengembangan UMKM memiliki nilai rata-rata sebesar 3.95 yang termasuk dalam kategori tinggi.

\section{KESIMPULAN}

Berdasarkan hasil analisis deskriptif, peran pemerintah terhadap pengembangan UMKM termasuk dalam kategori sangat tinggi. Hal ini berarti pemerintah kota Pangkalpinang sudah sangat baik dalam mendukung pengembangan UMKM. Peran 
pemerintah yang paling dirasakan yaitu dalam bentuk pembinaan serta koordinasi dengan para pelaku UMKM. Selanjutnya, peran akademisi terhadap pengembangan UMKM termasuk dalam kategori tinggi. Para akademisi khususnya di Pangkalpinang sudah dirasa baik dalam melakukan sinergi dengan pemerintah maupun pelaku UMKM sendiri baik dalam bidang penelitian, maupun pengabdian kepada masyarakat yang berkaitan dengan UMKM.

\section{DAFTAR PUSTAKA}

Darwanto, Dani Danuar. 2013. Pengembangan Usaha Mikro Kecil dan Menengah (UKM) berbasis Ekonomi Kreatif di Kota Semarang. DIPONEGORO JOURNAL OF ECONOMICS Volume 2, Nomor 4, Tahun 2013, Halaman 1-13, http://ejournal-s1.undip.ac.id/index.php/jme ISSN (Online): 2337-3814.

Daulay, Zul Asfi Arroyhan. 2018. Strategi Pengembangan Ekonomi Kreatif dengan Metode Triple Helix (Studi Pada UMKM Kreatif di Kota Medan). Tansiq, Vol. 1, No. 2, Juli-Desember 2018.

Hendrawan, Andi dkk. 2019. Dimensi Kreativitas dan Pengembangan Usaha Mikro Kecil dan Menengah (UMKM). Jurnal HUMMANSI (Humaniora, Manajemen, Akuntansi) Vol. 2 No. 1, Maret 2019, https://doi.org/10.33488/1.jh.2019.2.194.

Kristiyanti, Mariana. 2012. Peran Strategis Usaha Kecil Menengah (UKM) dalam Pembangunan Nasional. Jurnal Majalah Ilmiah Informatika Vol. 3 No. 1 Januari 2012.

Kurniawati, Dewi dkk. 2015. Identifikasi Faktor Pengembangan UMKM (Studi Kasus Pusat Kuliner Belut Godean Sleman Yogyakarta). Prosiding The 1st National Student Seminar on Agricultural Technology 2015Yogyakarta, 25 Agustus 2015, ISBN 978-602-73468-0-2.

Marlinah, Lili. 2019. Pentingnya Peran Perguruan Tinggi dalam Mencetak SDM yang Berjiwa Inovator dan Technopreneur Menyongsong Era Society 5.0. Jurnal IKRAITH Ekonomika Vol. 2 No. 3 November 2019.

Prayitno, dkk. 2019. Peran Politeknik Mengembangkan UMKM dalam Persaingan Global. Jurnal MONEX Vol. 8 No. 1 Januari 2019 p-ISSN: 2089-6778e-ISSN: 2549-5054.

Putra, Taranggana Gani. 2015. Peran Pemerintah Daerah dan Partisipasi Pelaku Usaha dalam Pengembangan UMKM Manik-Manik Kaca di Kabupaten Jombang. Jurnal Kebijakan dan Manajemen Publik. Vol. 3 No. 1 Januari-April 2015, ISSN: 2303$341 X$.

Ramadini, Frida dan Inggrita Gusti Sari Nasution. 2016. Strategi Pengembangan UKM Batik di Kota Medan. National Conference of Applied Sciences, Engineering, Business and Information Technology. Politeknik Negeri Padang, 15 - 16 Oktober 2016. ISSN:2541-111x.

Sobana, Dadang Husen dkk. 2018. Membangun Kemitraan Universitas dengan Pemerintah Daeran dalam Pengembangan Ekonomi Kreatif berbasis Syari'ah di Jawa Barat. Jurnal Hukum Ekonomi Syariah Volume V/ Nomor 2/ Juli 2018.

Sugiyono. 2014. Metode Penelitian Kuantitatif Kualitatif dan R\&D. Bandung: Alfabeta.

Sulastri, Reni dan Nova Dilastri. 2014. Model Pengembangan Usaha Kecil Menengah (UKM) Kerajinan Sulaman dan Bordir dengan Triple Helix di Sumatera Barat. Polibisnis, Vol. 6 No. 2 Oktober 2014 ISSN 1858 - 3717. 
Sulastri, Reni dan Nova Dilastri. 2015. Peran Pemerintah dan Akademisi dalam Memajukan Industri Kreatif: Kasus pada UMKM Kerajinan Sulaman di Kota Pariaman. SNEMA-2015 Book of Proceedings, ISBN: 978-602-17129-5-5.

Undang-Undang Nomor 20 Tahun 2008 Tentang Usaha Mikro, Kecil, dan Menengah.

Wahyudiono, 2018. Optimalisasi Peran Perguruan Tinggi dalam rangka memperkuat Daya Saing Umkm Kawasan Wisata Religi di Jawa Timur. Prosiding Seminar Nasional Manajemen 3dan Call For Papers 2018, E-ISSN: 2654-3664.

Wuryandani, Dewi dan Hilma Meilani. Peranan Kebijakan Pemerintah Daerah dalam Pengembangan Usaha Mikro, Kecil, dan Menengah di Provinsi Daerah Istimewa Yogyakarta. Jurnal Ekonomi dan Kebijakan Publik, Vol. 4 No. 1 Juni 2013.

Yurilsya, Muhammad dan Kasyful Mahalli. 2012. Peranan CSR PT. ARUN NGL dalam Pengembangan UKM di Aceh Utara. Jurnal Ekonomi dan Keuangan Vol. 1 No. 1. 